\title{
Dynamics of the social network of young female transsexuals that live and deal with HIV/AIDS
}

\author{
Dinâmicas da rede social das jovens transexuais femininas que (con)vivem com HIV/aids \\ Dinámicas de la red social de las jóvenes transexuales femeninas que (con)viven con VIH/sida
}

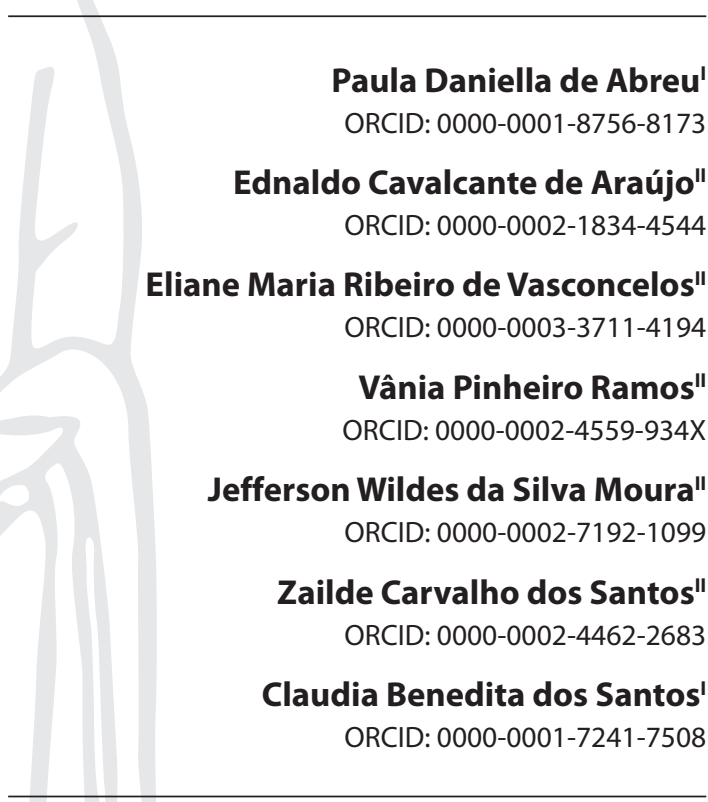

'Universidade de São Paulo. Ribeirão Preto, São Paulo, Brasil. "Universidade Federal de Pernambuco. Recife, Pernambuco, Brasil.

How to cite this article: Abreu PD, Araújo EC, Vasconcelos EMR, Ramos VP, Moura JWS, Santos ZC, et al. Dynamics of the social network of young female transsexuals that live and deal with HIV/AIDS. Rev Bras Enferm. 2018;72(5):1251-7. doi: http://dx.doi.org/10.1590/0034-7167-2018-0289

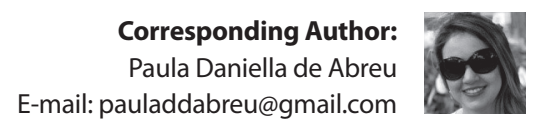

Submission: 05-04-2018

Approval: 07-24-2018

\section{ABSTRACT}

Objective: to analyze the social network of young female transsexuals who live with HIV/AIDS. Method: descriptive and exploratory study of qualitative approach, based on the Social Network Theory, developed in a Brazilian reference hospital for HIV/AIDS, with six transsexual women. Individual interviews were recorded and transcribed, and the data were subjected to analysis of similarities through the software program IRaMuTeQ. Results: the categories observed were: 1) dynamics of primary social network and social challenges; 2) dynamics of secondary social network and the institutional prejudice. Final considerations: the dynamics of the social network is based on the lack of support of primary and secondary networks, and the containment process limits the reach of quality of life and social emancipation. To deal with this theme will provide the visibility of young female transsexuals in confronting vulnerabilities and guaranteeing human rights.

Descriptors: Nursing Care; Family Nursing; HIV infections; Social Support; Transgender Persons.

\section{RESUMO}

Objetivo: analisar a rede social de jovens transexuais femininas que convivem com HIV/ aids. Método: estudo descritivo, exploratório, de abordagem qualitativa, fundamentado na Teoria de Rede Social, desenvolvido em um hospital de referência para HIV/aids, com seis mulheres transexuais. As entrevistas individuais foram gravadas e transcritas, e os dados foram submetidos a análise de similitude pelo software IRaMuTeQ. Resultados: observaram-se as seguintes categorias: 1) dinâmicas da rede social primária e os desafios sociais; 2 ) dinâmicas da rede social secundária e o preconceito institucional. Considerações finais: a dinâmica da rede social está alicerçada na falta de suporte das redes primárias e secundárias, e o processo de contenção limita o alcance da qualidade de vida e a emancipação social. Tratar deste tema irá oportunizar a visibilidade das jovens transexuais para o enfrentamento das vulnerabilidades e para garantia dos direitos humanos.

Descritores: Cuidados de Enfermagem; Enfermagem Familiar; Infecções por HIV; Apoio Social; Pessoas Transgênero.

\section{RESUMEN}

Objetivo: analizar la red social de jóvenes transexuales femeninas que conviven con VIH/ sida. Método: estudio descriptivo, exploratorio, de enfoque cualitativo, fundamentado en la Teoría de Red Social, desarrollado en un hospital de referencia para $\mathrm{VIH} / \mathrm{sida}$, con seis mujeres transexuales. Las entrevistas individuales fueron grabadas y transcriptas, y los da tos se sometieron a análisis de similitud por medio del programa informático IRaMuTeQ. Resultados: se observaron las siguientes categorías: 1) dinámicas de la red social primaria y los desafíos sociales; 2) dinámicas de la red social secundaria y el prejuicio institucional. Consideraciones Finales: la dinámica de la red social está fundamentada en la falta de soporte de las redes primarias y secundarias, y el proceso de contención limita el alcance de la calidad de vida y la emancipación social. Tratar de este tema favorecerá la visibilidad de las jóvenes transexuales para el enfrentamiento de las vulnerabilidades y para la garantía de los derechos humanos.

Descriptores: Cuidados de Enfermería; Enfermería Familiar; Infecciones por VIH; Apoyo Social; Personas Transgénero. 


\section{INTRODUCTION}

The youth can be comprised as the period from 15 to 24 years of age, a period marked by the search for independence, assertiveness and belonging to groups for the facing of new responsibilities ${ }^{(1)}$. The process of consolidation of the young female transsexual's identity is permeated by elements that comprise the feminine universe, perceived since childhood or adolescence, and by the search for new experiences, which are intensified based on the transformation of the body, usually associated with the lack of support by the social network. Indiscriminate use of hormones, obtainment of income through prostitution for survival and night circulation on the streets configure ambivalent situations, permeated by risk/pleasure and violence/acceptance in the sharing of vulnerabilities ${ }^{(2)}$.

Young female transsexuals are among the most marginalized people in the world, given that they experience a context of vulnerability resulting from the denial of social and health rights, associated with prejudice; violence; and barriers to access to healthcare, education and employment ${ }^{(3)}$. Considering the insertion of young female transsexuals in the labor market, positions in the fields of telemarketing, beauty and food, besides prostitution, are the most occupied, especially by those with low education, low socioeconomic status and that were expelled from the family nucleus ${ }^{(4)}$. According to a survey conducted in the United Kingdom, 36\% of transsexual people formally working already resigned from their jobs due to the discrimination, and up to $60 \%$ of them have suffered violence committed by transphobic individuals at work ${ }^{(5)}$.

In the United States of America (USA), violence at school and family rejection are the main causes of the suicide of trans people. On average, $45 \%$ of young transsexuals from 18 to 24 years of age have already attempted suicide, particularly those who are HIV-positive, of whom $51 \%$ have already tried to commit suicide ${ }^{(6)}$.

With regard to health institutions, according to the Transgender Europe, female transsexuals face episodes of discrimination and violence, these being the main barriers to the access to healthcare services at a global scale. Commonly these people receive no trans-specific health care, nor have access to trans-inclusive sexual education materials ${ }^{(7)}$.

Knowing the dynamics of social networks enables the analysis of the relational and affective flows of family and social dimensions, being an important resource of health care for people in a vulnerability context. Primary social networks include ties of family, kinship, friendship, neighborhood and work, as secondary social networks consist of relationships established between subject and institutions, as well as organizations of the market and of the third sector ${ }^{(8)}$.

To enable the visibility of young female transsexuals who live with HIV/AIDS for achievement of the integral health care motivated this study about the dynamics of the social network, aiming at analyzing circumstances, critical events, exhaustions, interruptions, and possible transgressions that impact the existing power relations and interfere in the health/disease process. Therefore, this study aims at responding the following guiding question: what is the dynamics of the social network of young female transsexuals who live with HIV/AIDS?

\section{OBJECTIVE}

To analyze the social network of young female transsexuals who live with HIV/AIDS.

\section{METHOD}

\section{Ethical aspects}

This research constitutes the delimitation of a thesis developed in the Graduate Program in Nursing of the Universidade Federal de Pernambuco (UFPE), whose project was approved by the Research Ethics Committee of the Center for Health Sciences of the UFPE (CCS/ UFPE) and followed the norms established by resolution no. 466, December 12, 2012, of the Brazilian National Health Council of the Ministry of Health, which provides the guidelines and standards that rule the studies involving human beings, following ethical precepts of autonomy, non-maleficence, beneficence, justice and privacy ${ }^{(9)}$.

\section{Type of study}

This is a qualitative, descriptive and exploratory study, based on the social network theory, which comprises the access to the reality of human relationships for the analysis of challenges and resources available of facing. Thus, it investigates the nuances of the relational equilibrium that, when broken, causes the risk of vulnerability ${ }^{(8)}$.

\section{Methodological procedures}

\section{Study scenario}

The study scenario was a reference hospital for people with HIV/AIDS, located in Recife, Pernambuco. This location was chosen based on the criterion of intentionality, in virtue of the hospital having the characteristics necessary for the development of the research and concentrate the population of interest.

\section{Data source}

Study participants were young transsexual women. For composition of the sample, the criterion of saturation of responses was followed. The universe approached was six people, selected by progressive inclusion through representations, attitudes and practices. The saturation occurs when the deepening, scope and diversity are reached for comprehension of representation, concepts, ideas and meanings assigned to the phenomenon elucidated in the light of the theory elected, aiming at providing a theoretical basis for the questions listed from their multi-faces and interconnections, without worrying about the generalization ${ }^{(10)}$.

The study participants were six young transsexual women, being considered the definitions of "youth" according to the World Health Organization (WHO) and the Ministry of Health ${ }^{(1)}$, that characterize the period as that from 15 to 24 years of age. However, aiming at minimizing biases related to possible stigma of parents or guardians, female young persons older than 18 were included in the study. 
Participants were selected by convenience sampling, according to the following predefined criteria: transsexuals identified with the female gender, having not undergone male-to-female transsexual surgery, heterosexual, HIV-positive or on treatment for AIDS and with casual partners. The approach with the participants was intermediated by the multiprofessional team of the hospital. People with hearing disability were excluded, since the researcher had no domain of Brazilian Sign Language (LIBRAS Língua Brasileira de Sinais).

\section{Data collection and organization}

Production of empirical data occurred from April to June 2017. Previous contact with the institution was made for obtaining the consent and approval of the multiprofessional team. This team was previously informed about the purpose of the research, the objective proposed and the procedures for data collection. They were invited to assist in the recruitment of transsexual women, according to the availability of professionals, without implying changes in the service routine. The invitation to participate in the research took place in the waiting room of the hospital, and if accepted, the participants were led to a private room reserved by the institution to respond to an individual interview.

The planning for elaboration of the interview guidelines was considered necessary to achieve the objective proposed and was conducted through necessary adjustments performed with the aid of professionals experienced on the subject To ensure the quality of the research a pilot test was carried out, developed with the first three participants. This test did not show the need of modifying the interview guidelines; thus, all participants were included in the sample. The guidelines of the semi-structured interview consisted of three guiding questions: 1 ) "tell me about your life story" (childhood, family, friends, companions, co-workers, remarkable facts, school, work, health services); 2 )"tell me what it means to you to live with HIV/AIDS"; and 3) "how do you perceive the social relations in the everyday lives of young transsexuals that live with HIV/AIDS?". Interviews had a mean duration of one hour and ten minutes. Reports were recorded, transcribed in full and submitted to analysis.

The meeting provided verbal communication for obtaining information on the scientific content elected, given that it features representations of the acting, the thinking and the feeling, under the influences of social dynamics in vulnerable groups, showing the reality in a singular form ${ }^{(11)}$. The study could explore the construction of knowledge and perceptions of the interviewees in order to understand, in depth, the individual amidst the social interaction in the elaboration of representations and conceptions of sense ${ }^{(12)}$. The semi-structured interview allowed the participants to freely discuss and talk about the questions ${ }^{(11)}$. Thus, rigid guidelines were not followed, but they only assisted the researcher in considering all relevant aspects to the study ${ }^{(13)}$.

\section{Data analysis}

The corpus of analysis was processed through lexical analysis technique, with the aid of the software program Interface de $R$ pour les Analyses Multidimensionnelles de Textes et de Questionnaires (IRaMuTeQ). This is a software that has been featuring prominently in the qualitative research, since it enables the methodological rigor and allows the performance of several types of analysis based on statistical techniques, being an important tool to assist in interpretation of results. Textual analysis of data was conducted through analysis of similarities, which is based on the graph theory. Such theory enabled the identification of co-occurrences in the structure of the representation and the obtainment of indications of the connectedness among words. Thus, the tree of similarity of the textual corpus was obtained, guided by the hierarchization through connections between terms and their adjacencies for each class identified ${ }^{(14)}$.

\section{Validity and reliability/rigor}

Methodological rigor was ensured through regular meetings with the team members involved in the research. Sampling methods, generation and interpretation of data were discussed. The interviews were transcribed in full over the period of data collections, as a record of the research process. The method for data processing and analysis chosen allowed the congruent categorization and connection with the critical realistic methodology and the constructivist epistemology on which this study is based. The conduct and the report of this study were held in accordance with the Consolidated Criteria for Reporting Qualitative Research (15-16).

\section{RESULTS}

The interviewees were aged between 18 and 24 years, with a mean of 21.6 years. All participants were single. As for the educational level, two of them had not completed the elementary school, one had completed the elementary school, two had completed the high school, and one had completed the higher education. It must be highlighted that the six participants had several types of profession/occupation, being four sex workers, one hairdresser, and one that reported exercising the function of pedagogical support. Regarding the household monthly income, it ranged from $R \$ 468.00$ to $R \$ 2,811.00$; and as for religiosity, participants stated having no religion/beliefs. The textual corpus analyzed, as shown in Figure 1, evidences the interface of the results for analysis of similarities with the identification of the connections among the words spoken by the participants. It assists in determining the field structure for combating HIV/AIDS of young transsexuals based on the dynamics of the social network in the context of vulnerability and of the heteronormative model in force.

The analysis enabled the construction of the co-occurrence tree, with the information reported by the interviewees, based on aspects concerning the facing of HIV/AIDS (positive and negative experiences). Through empirical evidence from analysis of similarities, one can notice the most frequent expressions - no, study, preservative, transsexual, street, AIDS, sex, family, hospital and the connections between words, in the light of the referential of social network, to analyze the dynamics of the primary and secondary networks of young female transsexuals, associated with prejudice and vulnerability of individual, contextual and programmatic origin, aiming at highlighting the dynamics of the primary social network and social challenges, as well as the dynamics of the secondary social network and the institutional prejudice. 


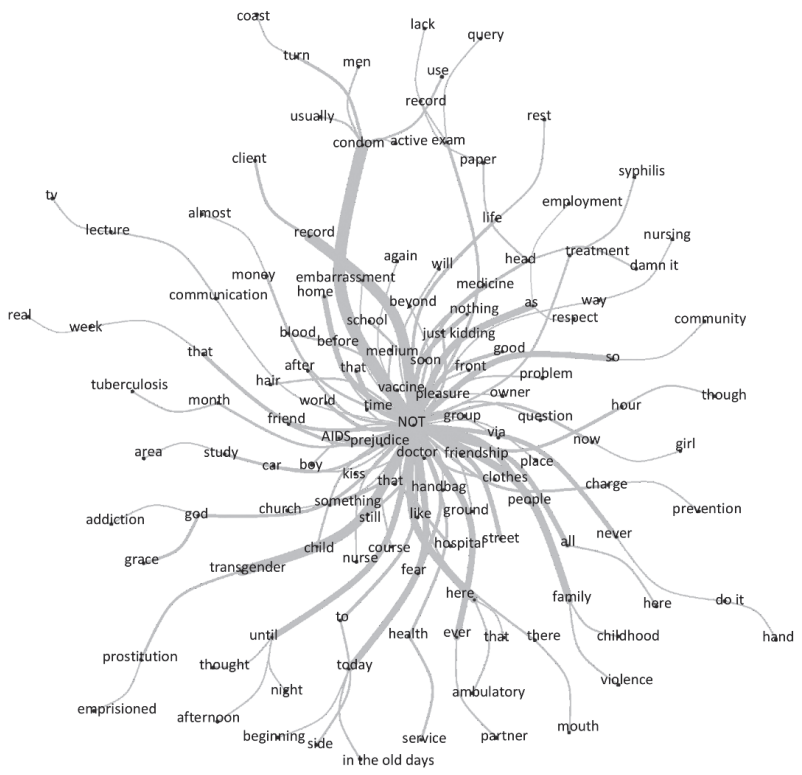

Source: Corpus of analysis processed by the software IRaMuTeQ 0.7 alpha 2

Figure 1 - Illustrative tree of analysis of similarity for the free associations of young female transsexuals to the inductor stimulus"tell me about how you perceive the HIV/AIDS in your everyday life", Recife, Pernambuco, Brazil, 2018

\section{DISCUSSION}

The analysis of the social network of young female transsexuals who live with HIV/AIDS forms an important empirical research for unveiling of the nuances that permeate human relationships anchored in the vulnerability context. The dynamics of primary and secondary social networks provides a relevant basis for the scientific implications in the field of health, especially for the care focused on subjectivities ${ }^{(8)}$.

The nurse integrates and collaborates with the multiprofessional team in the implementation of healthcare actions on the networks, and may assume the function of operator, a professional of reference in the construction of interventions. The dynamic character of social bonds establishes peculiar forms of understanding and acting in a humanized way in the comprehensive care of the female transsexual youth.

\section{Dynamics of the primary social network and the social challenges}

The factors that constitute the primary social networks are: life story, meetings and events over vital cycles. The birth demarcates the beginning of the story and of the construction of each individual's network, since family is the first welcoming nucleus that has the functions of education, care, social transaction and protection, directing and determining the subsequent relations ${ }^{(8)}$.

From the verbalizations about the life story related to the construction of the transsexual identity and to the family relations, we could note that youth is a challenging period in the transsexual women's life cycle, because in such moment the expression of femininity becomes more operational and thus represents the rupture of normativity. In general, the family creates expectations of the possible reversal of female behavior and, after identifying the irreversibility, the relational bonds are weakened or broken.
One can perceive a progressive vulnerability of the support resources that constitute the primary network:

I looked at women and thought: "wow, I wish I were her, dressed like her, had the delicacy that she has." I wished to be a woman and since I was a little one it was difficult, because my mother, my father never accepted me: "this kid when he grows up he will get better".(16)

The family nucleus should perform the function of main support network to the individual, the first cultural resource for education and social foundation for the affective construction ${ }^{(8)}$. However, the exclusion process within the familiar scope influences negatively the construction of one's subjectivity in the relationship with oneself and with the world ${ }^{(2)}$. The outcome is the distance of the family nucleus in a violent manner and the search for support for socialization in the streets:

I didn't want to continue my life at home dressing as a man and when I turned 18 I just waited to finish my education. I decided to leave, went to the world, and in the world what welcomes us that are trans? It's only prostitution. (16)

The rupture of family ties and daily discrimination leave them more vulnerable and deprived of rights ${ }^{(2)}$. In general, neighborhood ties play an important function of response to emergency situations due to physical proximity; whereas the friendship relations consist in affective bonding, even with the physical distance, being expressed by loyalty and sharing of experiences of joy and pain, having thus as competence the offer of appropriate advice ${ }^{(8)}$.

The young transsexuals reported the context of prejudice in the neighborhood and the welcoming by people of friendship familiarity. The bonds of friendship are reinforced in the sharing of new challenges that constitute the female transsexual youth's reality, marked by social exclusion, as in the acquisition of income through prostitution and in the everyday life with vulnerability to HIV/AIDS, expressed in the following lines:

One day I was on the street, with normal clothes, and then he [neighbor] yells: "Hey queen [mona], you're going to the streets, right? You're missing a heel over there." He didn't even respect my mother. My mother went over there, spoke with his wife and spoke to him, that if he didn't stop she was going to call the police, that this is homophobia and is a crime, you go to jail. (I5)

Nobody wants to give a job to trans, like, right away, and I was still starting that weird thing, then my friend did it, there's street nearby, let's go? It was in that let's go that I discovered it and remained there until today. (15)

I started to prostitute myself at 17. What marked me was when I found out I had AIDS. (I1)

On the other hand, the being of rights must be thought in the context of public health as target of empowerment strategies. Female young transsexuals must be perceived as potential modifiers of their own reality. Given this, the rhetoric of representing the transsexual youth as a social problem must be deconstructed:

I focused on my studies to work, not to live of prostitution, right? My relationship with my mother was very troubled, because she didn't 
accept me, she's already came to me and said she'd have preferred a drug addict. I went to college, work in the area and today my familysees me in a different way, they accept me, respect me, my mother, too. (I3)

\section{Dynamics of the secondary social network and the institu- tional prejudice}

Given the shortage of primary support, there is a sense of dependence of young female transsexuals in relation to secondary networks that, instead of promoting support, exercise a containment function. Truancy by young transsexuals, for example, results from the prejudice and the constant situations of violence generated by students and teachers: not using the legal name when calling the roll, the lack of access to toilet/changing room according to their gender, the exclusion in the activities due to binary divisions, and the everyday life marked by physical and psychological violence, as well as negligence. One can perceive the impact of female transsexual abjetification (abjetificação) that outlines youth as an experience of exclusion and suffering ${ }^{(7)}$.

A woman was applying a school activity, telling that we would take a test, then I asked her to call me by my legal name, she said she couldn't, that she was supposed to call me by the name that was in the notebook, at the same time I got up and left crying the room, then I went to the school administration office, shaking, then they asked me what had happened, I told them and the woman was spoken to, then the Principal told her she had to call me by my legal name, me, a girl all dressed up, to be called by a boy's name. (I5)

Gender is associated with the sociocultural ideology, being used as a resource for political, cultural and power domination, restricting and preestablishing socially acceptable behaviors, and punishing those who express their ontological being ${ }^{(17)}$.

One can notice that the relations established between young female transsexuals and healthcare services are terminated due to lack of welcoming ${ }^{(3)}$. The increasing mortality related to HIV/ AIDS in this stage of life is a strong indicator of the inefficiency of Brazilian public policies, being urgent to cause changes in the public health field for construction of effective strategies of research, health promotion and HIV/AIDS prevention.

The results of this study show the fragmentation of care, which includes negative experiences of sexist and binary source, besides the lack of health support that considers the vulnerability context of the population with HIV/AIDS ${ }^{(18)}$. Despite the low offer of longitudinal care in health services of greater complexity, the young female transsexuals reported opting for specialized care in order to fulfil their health requirements, at the expense of the continuity of patient care in the Brazil's Family Health Strategy (ESF - Estratégia de Saúde da Família), due to the following barriers: breach of confidentiality, lack of welcoming, not being called by the legal name, and unpreparedness of health professionals to meet their specific needs.

Health service unit I attended when I was a kid, now I don't go anymore, to any of them, I don't have, I go to the center where I live and I don't even want to, people there like to talk, what they discover they spread, I want that far away, that's why I already came from there to here [clinic], so no one can know, because homophobes discriminate everything, health professionals too. (14)
The health center is always full, the neighborhood I live is small, I'm afraid of exposure, since the day I went there with suspected chikungunya and she looked at my spotted hand and applied VDRL, which is for syphilis, I felt that it was not a thing that secretive and thought: I won't be coming back here to be embarrassed, I prefer the clinics, to come here and forget about everything, our emergence is here, in the center my need as a trans woman is not fulfilled. (I5)

Youth is intrinsically pervaded by socially divergent behaviors, requiring a primary network that welcomes and protects these female young persons ${ }^{(19)}$. However, patriarchal and necropolitical attitudes, which insist on keeping the hegemonic cisgender standard, contribute to the exposure and vulnerability of female young transsexuals ${ }^{(17)}$. Such vulnerability results in expansion of the dependence on secondary social networks. The prison system, for example, is configured as a young female transsexuals' maximum point of distance of their primary network and as space permeated by violence, social abandonment and susceptibility to HIV/AIDS:

When I was arrested people obliged me to have sex without a condom in prison I had sex without a condom... There is no one who goes there to give some support, to say "I'm with you until the end." (16)

Networks of the third sector are comprised of cooperatives or non-profit social associations, formed to provide attention to the existing social reality based on the relationship of loyalty and of sharing of common values ${ }^{(8)}$. Non-governmental organizations (NGOs) establish support relations for empowerment and social activism, being an important network for combating HIV/AIDS. The critical and dialogic struggle to combat transphobia and to promote health for the young persons living with HIV/AIDS is a collective commitment that covers citizenship and human rights ${ }^{(20)}$.

The evidence and mobilization that show the young female transsexuals' desire for visibility must be valued by operators, health professionals, that form the network, given that the manifesto of solidarity is the foundation required to strengthen the relational ties of care and the dialogical actions, aiming at achieving the autonomy of these young persons:

I see that there are various NGOs that are always giving speeches, but I think they should improve more, because there are many trans that are laypeople, don't know about the disease, and I think that they should improve more the communication about the disease, explaining how to catch it. (I3)

\section{Study limitations}

The phenomenon in which this study focuses is inserted in a social, historical and healthcare context of health, marked by prejudices and stigmas, given that personal beliefs and moral precepts instigate judgements that end up leaving female young transsexuals on the sidelines of society. This process may have made difficult the verbalization and the collaboration of the interviewees with the research.

\section{Contributions to the field of nursing, health or public policy}

Health services must incorporate the guidelines of policies for humanization, health promotion and, in particular, for holistic 
health of the LGBT population, in order to offer a better welcoming and care to the specific needs of this group. This study explains the need for encouraging the participation of health professionals in the training courses offered by the Ministry of Health, educational actions carried out by district coordinators of the LGBT policy and discussions conducted by social movements. The incorporation of the topic in the academic curriculum in mandatory, both in isolation, to problematize its specificities, as in context, in the other disciplines, given that health education is a continuous process that must be built from scientific knowledge combined with the popular knowledge in an inseparable articulation of the social network, education, research and social activism for a joint construction of knowledge.

\section{FINAL CONSIDERATIONS}

This study states the existence of a historical and social context of vulnerability that contributes to the susceptibility to HIV/AIDS, being originated in the dynamics of the social network, associated with the syndrome, the actors and the social sectors, and exposed empirically in the everyday lives of transsexual women, which hinders the fight against the disease. This process results in weaknesses in the network to deal with the disease before a possible social death. For these people, the positive result for HIV in the youth represented the imminence of doubts about the illness and difficulties of living with this new reality.

To the state of art in the health field, this study contributes to expand and deepen the understanding of relational interactions within social networks, from bonds of support and containment and relationships of adversity and confrontation established in the context of vulnerability before actions promoted by the health sector.

With regard to the nurse, this study provides subsidies for reflecting on the professional practices towards a better preparation to act in the support of transsexual women, recognizing and intervening with other sectors aimed at ensuring their rights of use and access to goods and services as any other citizen, in accordance with the Brazilian Federal Constitution (Constituição Federal Brasileira).

\section{ERRATUM}

Article "Dynamics of the social network of young female transsexuals that live and deal with HIV/AIDS", with number of DOI: http://dx.doi.org/10.1590/00347167-2018-0518, published in the journal Revista Brasileira de Enfermagem, v72(4): 1251-7, on page 1251:

Where it read:

'Universidade Federal de Pernambuco. Recife, Pernambuco, Brasil.

" Universidade de São Paulo. Ribeirão Preto, São Paulo, Brasil.

Read:

' Universidade de São Paulo. Ribeirão Preto, São Paulo, Brasil.

"Universidade Federal de Pernambuco. Recife, Pernambuco, Brasil.

\section{REFERENCES}

1. Ministério da Saúde (BR), Secretaria de Atenção à Saúde, Departamento de Ações Programáticas e Estratégicas. Proteger e cuidar da saúde de adolescentes na atenção básica [Internet]. Brasília, DF:; 2017 [cited 2018 Mar 10]. Available from: http://189.28.128.100/dab/docs/ portaldab/publicacoes/saude_adolecentes.pdf

2. Silva RGLB, Bezerra WC, Queiroz SB. Os impactos das identidades transgênero na sociabilidade de travestis e mulheres transexuais. Rev Ter Ocup Univ São Paulo [Internet]. 2015 [cited 2017 Oct 22];26(3):364-72. Available from: http://www.revistas.usp.br/rto/article/view/88052

3. Unaids. Prevention gap report [Internet]. Geneva: Unaids; 2016 [cited 2017 Oct 22]. Available from: http://www.unaids.org/sites/default/ files/media_asset/2016-prevention-gap-report_en.pdf

4. Marinho S. Juventude(s) trans: subjetividades e corporalidades possíveis no mundo do trabalho? O Social em Questão [Internet]. 2017 [cited 2017 Oct 22];(38):111-32. Available from: http://osocialemquestao.ser.puc-rio.br/media/OSQ_38_art_6_Marinho.pdf

5. Totaljobs. Trans employee experiences survey 2016 [Internet]. London: Totaljobs; 2016 [cited 2018 Feb 22]. Available from: https://www. totaljobs.com/insidejob/trans-employee-survey-report-2016

6. Haas AP, Rodgers PL, Herman JL. Suicide attempts among transgender and gender non-conforming adults: findings of the national transgender discrimination survey [Internet]. New York: American Foundation for Suicide Prevention; 2014 [cited 2017 May 5]. Available from: https://williamsinstitute.law.ucla.edu/wp-content/uploads/AFSP-Williams-Suicide-Report-Final.pdf

7. Fedorko B, Berredo L. O círculo vicioso da violência: pessoas trans e gênero-diversas, migração e trabalho sexual [Internet]. Malmö: Transgender Europe; 2017 [cited 2018 Apr 1]. Available from: https://transrespect.org/wp-content/uploads/2018/01/TVT-PS-Vol19-2017.pdf

8. Sanicola L. As dinâmicas de rede e o trabalho social. 2a ed. São Paulo: Veras; 2015.

9. Ministério da Saúde (BR), Conselho Nacional de Saúde. Resolução n 466, de 12 de dezembro de 2012. Diário Oficial da União [Internet]. 2013 [cited 2017 Dec 15];1:59. Available from: http://bvsms.saude.gov.br/bvs/saudelegis/cns/2013/res0466_12_12_2012.html

10. Minayo MCS. Amostragem e saturação em pesquisa qualitativa: consensos e controvérsias. Rev Pesqui Qualitativa [Internet]. 2017 [cited 2017 Dec 15];5(7):1-12. Available from: https://edisciplinas.usp.br/pluginfile.php/4111455/mod_resource/content/1/Minayosaturacao.pdf

11. Minayo MCS, organizador. Pesquisa social: teoria, método e criatividade. 29a ed. Petrópolis: Vozes; 2015. 
12. Bauer MW, Gaskell G. Pesquisa qualitativa com texto, imagem, e som: um manual prático. 5a ed. Petrópolis: Vozes; 2015.

13. Yin RK. Pesquisa qualitativa: do início ao fim. Porto Alegre: Penso; 2016.

14. Camargo BV, Justo AM. IRaMuTeQ: um software gratuito para análise de dados textuais. Temas em psicologia [Internet]. 2013 [cited 2018 Mar 3];21(2):513-8. Available from: http://pepsic.bvsalud.org/pdf/tp/v21n2/v21n2a16.pdf

15. Maxwell JA, Miller B. Real and virtual relationship in qualitative data analysis. In: Maxwell JA. A realist approach for qualitative research. Los Angeles: SAGE Publications; 2012.

16. Booth A, Hannes K, Harden A, Noyes J, Harris J. COREQ (Consolidated Criteria for Reporting Qualitative Studies). In: Moher D, Altman D, Schulz K, Simera I, Wager E, editors. Guidelines for reporting health research: a user's manual. Oxford: John Wiley \& Sons; 2014.

17. Caravaca-Morera JA, Padilha MI. Social representations of sex and gender among trans people. Rev Bras Enferm [Internet]. 2017 [cited 2018 Jan 17];70(6):1235-43. Available from: http://www.scielo.br/pdf/reben/v70n6/0034-7167-reben-70-06-1235.pdf

18. Divan V, Cortez C, Smelyanskaya M, Keatley J. Transgender social inclusion and equality: a pivotal path to development. J Int AIDS Soc [Internet]. 2016 [cited 2017 Oct 22];19(3):20803. Available from: https://www.ncbi.nlm.nih.gov/pmc/articles/PMC4949312/

19. Nunes MR, Ferriani MGC, Malta DC, Oliveira WA, Silva MAI. Social network of adolescents under probation from the perspective of public health. Rev Bras Enferm [Internet]. 2016 [cited 2018 Feb 26];69(2):276-84. Available from: http://www.scielo.br/pdf/reben/v69n2/en_00347167-reben-69-02-0298.pdf

20. Seffner F, Parker R. The waste of experience and precariousness of life: contemporary political moment of the Brazilian response to aids. Interface [Internet]. 2016 [cited 2017 Oct 30];20(57):293-304. Available from: http://www.scielo.br/pdf/icse/v20n57/1807-5762icse-1807-576220150459.pdf 